geen maat te houden. De lezer wordt bedolven onder een lawine van informatie. Theoretische analyses die structuur zouden moeten aanbrengen, zoals de genoemde drie A's, worden wel genoemd maar niet geïntegreerd in het betoog. Veel theorieën die Paalman aanhaalt werken eerder verwarrend dan verhelderend en soms leiden ze tot absurde constateringen, bijvoorbeeld als hij een postmoderne architectuurtheoreticus loslaat op het Rotterdam van de jaren twintig (p. II3-II4).

In het radioprogramma $D e$ Avonden van de VPRO werd Cinematic Rotterdam 'een uitputtende studie' genoemd. Dat kan terugslaan op de hang naar volledigheid van de auteur, maar het kan ook betrekking hebben op het lezen van het boek. Dit is in de eerste plaats de auteur aan te rekenen, maar in de tweede plaats alle anderen die dit boek onder handen hebben gehad voor het naar de drukker ging. Waarom is er geen kordate eindredacteur aangetrokken voor noodzakelijke inkortingen? Veel passages gaan helemaal niet over film. Andere passages gaan niet over Rotterdam. Het op zichzelf interessante hoofdstuk over de regisseur Andor van Barsy had beter elders gepubliceerd kunnen worden. Waarom is het stugge Engels van de auteur niet geredigeerd? De enigen die geen blaam treft zijn de grafisch ontwerpers Piet Gerards en Maud van Rossum. Zij hebben de veelheid aan tekst en beeld in een aantrekkelijke en overzichtelijke vorm gegoten. Dit is een prachtig boek om in te bladeren en feitelijke informatie in op te zoeken.

Patricia van Ulzen

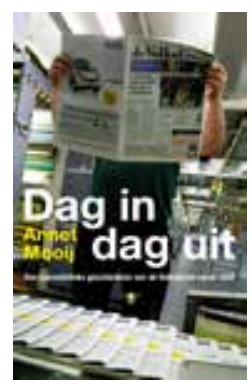

\section{Annet Mooij}

Dag in Dag uit. Een journalistieke geschiedenis van de Volkskrant vanaf 1980

Amsterdam (De Bezige Bij) 20II, 368 p.,

€ I9,90, ISBN 9789023465232

(www.debezigebij.nl/web/Webshop-detailpagina.

htm? ean $=9789023465232$ )

Geschiedenis van een redactionele

loopgravenoorlog

Van alle Nederlandse kranten is de geschiedenis van de Volkskrant zonder twijfel het best beschreven. Nadat Joan Hemels in I98I de institutionele en bedrijfsmatige contouren schetste van een katholieke krant die op het punt stond door te breken naar een progressief massapubliek (De emancipatie van een dagblad. Geschiedenis van de Volkskrant), voegde Frank van Vree daar in 1996 een veelgeprezen geschiedenis van de naoorlogse journalistieke ontwikkeling van het dagblad aan toe (De metamorfose van een dagblad. Een journalistieke geschiedenis van de Volkskrant). Van Vree's studie bood een buitengewoon scherp inzicht in de redactionele processen die leidden tot de succesvolle metamorfose van wat ooit een lijdelijk vakbondsblaadje was tot een kwaliteitskrant voor een breed progressief publiek. Maar bovenal was zij richtinggevend voor een nieuwe benadering in de persgeschiedenis; de aandacht werd verlegd van de institutionele context waarin journalistiek plaatsvond naar journalistieke cultuur en de normen, routines en processen op basis waarvan dagelijks een krant wordt gemaakt.

Annet Mooij gaat voort waar Van Vree ophield en beschrijft de geschiedenis van de Volkskrant tussen I980 en 2010. Niet zozeer de redactionele koers die de krant voer of hoe die gestalte kreeg in de kolommen interesseert haar, maar vooral de machtspolitiek en besluitvormingsprocessen op de redactie. Dat levert 
een buitengewoon prettig leesbaar boek op, met smeuige citaten, en een aaneenschakeling van intriges en conflicten. Mooij concentreert zich op personen en incidenten, en geeft zo een interessant inkijkje in de redactiecultuur van de Volkskrant. Dat ze daartoe toegang heeft gekregen - haar onderzoek werd net als dat voor de vorige twee boeken betaald door de krant - pleit voor het reflexieve klimaat dat bij de Volkskrant heerst. Net als eerder Gerard van Westerloo in een geruchtmakende reportage uit 1996 , verhaalt Mooij vrijuit en soms messcherp over de voortdurende gevechten op de redactie. Helaas komt ze aan de analyse die schuilgaat achter de beschrijving van al deze perikelen wat minder toe. Met iets meer helicopter-view had de historische analyse aan kracht gewonnen.

Mooij hangt haar analyse op aan de twee hoofdredacteuren die de krant in deze periode leidden: Harry Lockefeer (I982-I995) en Pieter Broertjes (I995-2010). Daarmee kiest ze voor een vergelijkbare aanpak als Ad van Liempt in zijn studie van het Nos-Journaal. Die beargumenteerde zijn periodisering met de claim dat hoofdredacteuren immer een grote invloed hadden op de koers van het programma. Maar wie Mooij's studie leest, kan zich moeilijk aan de indruk onttrekken dat dit bij de vrijgevochten Volkskrant-redactie net even iets anders lag.

Lockefeer opereerde als een tacticus die met behoedzaam manoeuvreren het 'veelkoppig monster' zachtjes in de gewenste richting dreef. Dat ging veelal gepaard met grotere en kleinere nederlagen, het likken van de wonden door de hoofdredactie, en vervolgens opnieuw proberen de zaak in beweging te krijgen. De vrijgevochten redactiecultuur van de Volkskrant had haar wortels in de ontvoogding van de jaren zestig en zeventig. De plenaire redactievergadering had volgens het redactiestatuut de mogelijkheid om over iedere beleidsverandering te stemmen. Dit gebeurde met grote gretigheid waardoor plannen vaak eindigden in een 'moeras van overleg, onenigheid en procedureel geneuzel'. De hoofdredactie leek de natuurlijke tegenstander van het collectief waarin een ieder zijn autonomie koesterde. Adjunct Bert Vuijsje sprak van 'systematische laatdunkendheid, pesterigheid en paranoia bij de heethoofden ter redactie, begeleid door het miezerige gegniffel van een brede middengroep'.

Broertjes trok aan het begin van zijn hoofdredacteurschap met veel elan de touwtjes strakker aan. Hij had het tij mee: in de dynamiek van verzakelijkende maatschappelijke verhoudingen, professionalisering en digitalisering van het productieproces, lukte het de hoofdredactie de eilandencultuur te doorbreken en meer greep te krijgen op de inhoud van de krant. Broertjes wilde de krant minder 'zuur' en eenzijdig links maken, en haar zowel in de opinievorming als de nieuwskeuze verbreden. Onderwerpen die onder Lockefeer als 'trivia' en plat werden bestempeld, kregen nu een plaats in de krant. Broertjes haalde ook journalisten van 'rechtse' media zoals Elsevier naar de krant, in het geval Hendrik Jan Schoo zelfs in de hoofdredactie. Multiculti versus neocon leidde in het Fortuyn tijdperk zelfs tot een heuse richtingenstrijd. Toch moest ook Broertjes, volgens Mooij, voortdurend schipperen. Het beleden ideaal van een open en pluriforme krant is zo beschouwd vooral het vermijden van keuzes en een strategie voor het apaiseren van de bloedgroepen ter redactie. Ingezet beleid werd voortdurend ad hoc bijgesteld, waarbij de uitvoering er nogal eens bij inschoot. 'Richtingloos gedobber' van een krant die op volle zee zoekende was naar haar identiteit.

Op verschillende momenten in haar boek wijst Mooij erop dat er ondanks het gekrakeel toch elke dag weer een krant verscheen. En dat de lezer dus weinig meekreeg van alle wrijving en er ook geen last van had. Het is jammer dat Mooij niet is toegekomen aan een analyse van de inhoud van de krant. Nu blijft onduidelijk hoe de beleidsvoornemens en conflicten ter redactie zich vertaalden op papier. Boeiend is haar observatie dat ondanks alles de loyaliteit aan de krant en aan elkaar groot was, en dat de competitie ter redactie niet alleen soms verlammend werkte op vernieuwingsplannen, maar wellicht ook en vooral de kwaliteit van de krant ten goede kwam. Het ware interessant geweest als zij toch op gerichte momenten de krant eens ter hand had genomen om dit soort veronderstellingen te toetsen.

Marcel Broersma 